\title{
The Role of Myth in Understanding Nature
}

\author{
Raymond Pierotti ${ }^{1^{*}}$ \\ ${ }^{1}$ Department of Ecology and Evolutionary Biology, University of Kansas, Lawrence, KS, USA. \\ "pierotti@ku.edu
}

\begin{abstract}
Use of metaphor embodies myth in Western science and Native American traditional knowledge traditions about understanding the "natural" world and the nonhuman "other." Using personal history, I compare a myth/metaphor from each intellectual tradition that shaped my thinking. Cultural trains of thought and metaphors impacted these myths and shaped my way of thinking. From Western scientific tradition, I examine the "Balance of Nature," which dominated ecology and conservation biology from the 1850s until the 1990s. Balance and stability underlie major models in contemporary ecology and population biology, especially in wildlife and fisheries management. Before I trained as a Western style evolutionary ecologist, the myth of Wolf as creator figure in the traditions of Numic peoples (Shoshone, Comanche, Ute, Paiute) was the Indigenous creation myth that shaped my thinking. In the Balance of Nature, hidden metaphors are rooted in Western economic thought, specifically Capitalism. Similar metaphors in Numic peoples assume that humans are related ecologically to wolves, who served as teachers and guides. Stories, rather than data, served to fix these concepts into each cultural tradition. Although Numic beliefs appear "irrational" to Western society, they are more attuned to twenty-first century ecological and evolutionary thought than balance in nature, which lay at the root of Western ecological ideas until the 1980s. I discuss how my experiences with changing environmental conditions combined with my work with Indigenous peoples. Exposure to philosophical and empirical approaches from ethnobiology led me to explore these themes.
\end{abstract}

Received June 19, 2016

OPEN ठACCESS

Accepted December 13, 2016

DOI 10.14237/ebl.7.2.2016.729

Keywords Shoshonean, Wolf, Balance of nature, Western science, Traditional knowledge, Myth

Copyright $@ 2016$ by the author(s); licensee Society of Ethnobiology. This is an open-access article distributed under the terms of the Creative Commons Attribution-NonCommercial 4.0 International Public License (https://creativecommons.org/licenses/by-nc/4.0), which permits non-commercial use, distribution, and reproduction in any medium, provided the original author and source are credited.

For much of my adult life I struggled with the idea of how myth relates to my understanding of how the world functions. In books and educational settings, it seemed that the idea of myth was employed to discuss ideas that are ultimately false, or at least untrue, but that were still important to learn about. In some of my family experiences, however, I got the feeling that myth referred to traditional stories and beliefs that emerged from specific cultural traditions and ways of relating to nature. In this latter sense, myth is not false, but so profound that it is strongly linked to personal identities and understanding of human relationships to other aspects of the world.

My current way of thinking is that "myth is a theorem about the nature of reality, expressed not in algebraic symbols or inanimate abstractions, but in animate narrative form" (Bringhurst 2008:63). Bringhurst further argues that "Myth is... an alternative form of science... an alternative form of investi-
gation...It aims, like science, at perceiving and expressing ultimate truths, but the bypotheses of myth are framed as stories, not as equations, technical descriptions or taxonomic rules... a story so perceptive of reality that it might be rediscovered, like any law of nature, in almost any culture at any time" (Bringhurst 2008:64, emphasis added).

"The final goal of metaphor is myth, which is a narrative derived from taking the figurative literally" (Charles Simic cited in Bringhurst 2008:67). Thus, in discussing myth we should determine the relationship between story and metaphor. As an evolutionary ecologist, I believe that it must be recognized that metaphor is an important aspect of the Western scientific tradition. Metaphors dominate both biological research and the way biological phenomena are understood under the Western tradition (Pierotti 2011a:68). "Contemporary philosophers have argued that scientific understanding, like all human under- 
standing, proceeds by way of providing metaphorical redescriptions of phenomena" (Hesse 1974:62). Native American traditional knowledge is typically presented in a metaphoric fashion, which has allowed some individuals of European ancestry to try to dismiss such knowledge as mere "stories" or "legends" (Anderson 2013, Pierotti 2011a). As I matured, I realized that these metaphors originate from Indigenous philosophical and spiritual traditions that derive knowledge from careful observation of relationships. Metaphorical stories lead to the fundamental Indigenous principles that "All things are connected," and "All things are related" (Pierotti 2011a, b).

Examining Western and Native American ways of knowing allowed me to compare metaphors and emerging myths employed in each tradition. The stories involved allowed me to reconsider the meanings of "natural" and the nonhuman "other." Two important myths, one from each intellectual tradition were important in influencing my early ways of thinking. From the Western scientific tradition, the myth of the "Balance of Nature" shaped my early training. This way of thinking led me to consider that natural populations and ecosystems exist in a state of equilibrium. This idea was important to my understanding of ecology and conservation biology. This was especially because I found such thinking in the writings of one of my early heroes, Charles Darwin. At the time, I regarded the Balance of Nature and equilibrium thinking not as myths or metaphors, but as descriptions of reality. These ideas underlay major models in ecology and population biology, and served as the basis of wildlife and fisheries management.

While I was growing up I was told the story of how Wolf served as creator figure in the traditions of Numic peoples (Shoshone, Comanche, Ute, Paiute). As a boy I found this a fascinating story, which led to my interest in wolves, but as a college student I found the story hard to understand in any literal sense, and I clearly did not fit within the ecological tradition in which I was being trained. In consequence, I filed these stories aside until I began working with Native American faculty and students at Haskell Indian Nations University in the 1990s. During this same period, I became aware of Gene Anderson's classic book, Ecologies of the Heart (1996). I was intrigued by how Anderson presented the idea of "error" or possible irrationality in belief systems, because of mistakes in the metaphors hidden within them. I was intrigued by how Anderson discussed how understanding these errors could lead to conflict or reconciliation. This led me to reconsider the stories I had heard as a boy with the education I had received as an ecologist in training. I thought it might be useful to examine my own apparently irreconcilable ideas to find the errors and irrationality they contained.

\section{Balance of Nature and Equilibrium Models}

"That there is a balance of nature is one of the most deep-seated assumptions about the natural world..." (Kricher 2009: 1). By replacing "deep seated assumption" with "myth," I could explore the irrational errors under the myth. The idea of balance in nature is powerful and logically intuitive. It underpins much of contemporary ecological thought, especially regarding the development of theory in population ecology. The Balance of Nature myth has been used to explain the functioning of natural ecological systems from ancient times. Aristotle viewed balance as perhaps the single most important component of the cosmos.

I found the error in teleological understanding of biological phenomena, which considered balance to be an expression of the mind of god. This was expressed in the idea that "to know god one should know nature." Such thinking underpinned the preDarwinian conception of the immutability of species (Kricher 2009) and showed that in the Balance of Nature, ecology allowed creationist thinking to enter through a back door.

In the earliest days of modern science, there was no quantitative underpinning to any of these ideas concerning balance in nature. Darwin assumed the existence of balance, which is implicit in his metaphor of the Tangled Bank. It is also explicit in his discussion of food webs and competition between species, "yet in the long-run the forces are so nicely balanced that the face of nature remains uniform for long periods of time" (Darwin 1859:73; Kricher 2009:65). Such thinking continues to be invoked in popular culture. A recent study showed that American undergraduates believe this term is descriptive of real ecological systems (as did I in my undergraduate days), and continue to do so even after instruction in ecological science (Zimmerman and Cuddington 2007).

Despite such beliefs, as a scholar I came to recognize that, "The notion of a balance of nature is part observational, part metaphysical and not scientific 
in any way" (Kricher 2009:16). As ecology became increasingly mathematical, however, the idea of balance was transformed into the idea that natural systems are always seeking a state of equilibrium. In the first scientific studies in animal ecology, Charles Elton stated that he was "chiefly concerned with what may be called the sociology and economics of animals," and that animals are "subject to economic laws" and defined food (calories) as the "currency" of animal economics (1927:vii, viii, 56). Such thinking can be seen in all of the classic models of population dynamics derived from the Lotka-Volterra equations (Kingsland 1985).

My first major research project as an ecologist involved studying male and female parental roles in the Western Gull, Larus occidentalis in the North Pacific. Gulls are monogamous, territorial birds that typically breed in colonies on islands (Tinbergen 1953). I was trained as a typical Western population ecologist steeped in the tradition of Elton, David Lack, and Niko Tinbergen, operating under the assumption that all individuals in a population or species were basically the same, and that if a territorial breeding bird was removed it would be readily replaced by a nonbreeder. Tinbergen was my role model, having written the classic The Herring Gulls' World.

I collecting detailed data on 25 pairs of gulls over two years. I quickly learned that individual variation in ecology and behavior within and among pairs undermined the idea that members of a species were similar and could readily be replaced. The first year took place under fairly severe El Nino conditions, where warmer less productive waters reduced availability of small fish and large plankton preferred by female gulls (Pierotti 1981). Males and females adjusted their schedules, so the behavior of individual pairs varied according to the foraging abilities and preferences of each parent. If a female took more time in finding food, her mate adjusted by spending more time sitting on the nest incubating the eggs. Variation in parental care brought home two things: 1) the behavioral flexibility of individual gulls and pairs, and 2) the importance of environmental variation in determining behavior in relation to ecology. Gulls could not anticipate from one year to the next what foraging conditions would be like. Such findings did not fit the "balance of nature" and "constant environmental conditions" type of thinking in which I had been trained (Pierotti 1981, 2011a).
For my Ph.D. I studied interactions among gulls, puffins, and humpback whales off the coast of Newfoundland. This system was driven by variation in the availability of capelin (Mallotus villosus), a small schooling fish that occurs in huge spawning aggregations during late spring and early summer. Capelin are so abundant that my predecessors studying this system assumed that capelin abundance was uniform over an area of hundreds of square kilometers.

In this study I employed Optimal Foraging Theory (OFT), developed during the 1970s. OFT is derived from economic models designed to optimize income within capitalist systems. Under OFT, it is assumed that foraging organisms always prefer the food type that yielded the highest rate of caloric intake, which maximizes this currency (Stephens and Krebs 1986). I found that food choice varied temporally in relation to local habitat, and that gulls did not take the food types highest in calories, but the ones that allowed them to produce the healthiest offspring. Switches in diet during the season related to the hatching of eggs and the presence of small chicks (Pierotti and Annett 1987, 1990, 1991). It became obvious to me that gulls had a very different view of the best diet was than did ecologists, animal behaviorists, or economists, and this was undermining my belief of the existence of a balance in nature.

I had been trained to employ theory to support the data I was collecting in behavioral and evolutionary ecology. Theory in these disciplines is based upon economic models employed as metaphors for what was presumed to be taking place in The Economy of Nature (Elton 1927; Worster 1993, 1994). Linnaeus first presented this concept in 1749 in his work Specimen Academicum de Oeconomia Naturae (Kricher 2009). The phrase was adopted by Darwin in his Origin of Species, and codified by Elton (1927). Elton originated, and OFT continued, the concept of "currencies," in terms of calories. In addition, Eltonian trophic dynamics speak in terms of "producers" and "consumers." The logistic model, employed to examine Lotka-Volterra dynamics assumes a constant environment and a fixed "carrying capacity." This model and its derivatives are the basis of wildlife and fisheries models, e.g. the notorious Maximum Sustainable Yield (MSY) models. MSY thinking led to the crash of virtually all marine fisheries on a global scale and is considered to be one of the most misleading concepts in the field of ecology and fisheries management (Finley 2011; Holt 
1975; Larkin 1977). Continuing gull research in California, we found great variability among individuals across twelve breeding seasons (Annett and Pierotti 1989, 1999; Pierotti and Annett 1990, 1994). All our studies showed that metaphors derived from economic concepts were not useful and even misleading, because the systems were constantly changing as El Nino events became more frequent, and the birds changed their behavior in attempts to track the changing conditions.

\section{Wolf as the Creator}

By the 1990s I was becoming frustrated by the theoretical and epistemological constraints imposed by Western thinking. During this decade I obtained a tenure track university position, that included the opportunity to work with Native American faculty and students at Haskell Indian Nations University. These colleagues led me to reconsider concepts from my upbringing in New Mexico, and the stories I had learned from my elders about thinking of all members of any species as individuals. What was considered to be the myths of Native Americans emphasized reciprocal relationships that they assumed to exist between humans and nonhumans. Considering how this type of thinking could be applied to my ecological research led me to read the work of gene Anderson, and started me on the path that led me to ethnobiology (Pierotti 2011 a,b).

One of the most important myths in the Numic (Shoshone, Comanche, Piute, Ute) tradition is that Wolf served as benevolent creator figure. This was one of the formative myths of my youth. As a professor, I recognized that Indigenous peoples employed very different concepts of "creation" or "origin," which related to environmental instability and fluctuations (Pierotti 2011a). In the Western tradition, when referring to humans, or even life itself, creation seems to refer only to first appearance of an entity. Thus, creation is a single event, which leads to creationist thinking among religious westerners, and to the idea of single origins of life forms within the sciences. In contrast, Native American creation stories refer to a series of events that are not located in specific periods of time, but instead are linked to a particular physical location where environmental conditions change in unpredictable ways. This forces these cultures to redefine themselves and develop new traditions and ways of coping with the new environmental conditions (Pierotti 2011a). Indigenous concepts of creation involve process, rather than a single event. It is recognized that humans existed prior to the events described as "creation," thus multiple creation events are possible, and creation is still taking place in the modern world.

Working with Indigenous people drove me to realization that many Native American cultural traditions were being established at the end of the Ice Ages, when conditions were highly variable. In North America, the "first" humans had to contend with massive flooding, unpredictable freezes, and intermittent warming, while having to eke out a living by hunting and gathering while animal populations changed dramatically. Deglaciation in the northern Hemisphere began about 20,000 ybp (Clark et al. 2009), which corresponds to most recent evidence concerning the timing of the peopling of the Americas (Dillehay et al. 2015; Gibbons 2015). Climate change has been a major driver of population size changes in both humans and nonhumans over the last 50,000 years (Gibbons 2013; Lorenzen et al. 2011; Pennisi 2004; Shapiro et al. 2004).

Thinking in this fashion led me to recognize that if creation stories deal with responses to changing environmental conditions, Indigenous cultures were attuned to thinking about variability rather than stability in the environment. Thus, any other species that helped them navigate these changes effectively was credited with great spiritual power, and in some circumstances, identified as the protagonist of a creation story.

From this thinking it was only a short step to realize that the Numic creation story I described above might be more than a colorful story, and could be a description of an important ecological relationship. Wolves were considered to be of great cultural and spiritual significance to many Indigenous American peoples (Fogg et al. 2015; Marshall 1995; Schlesier 1987). Wolves served as models for the concepts of community existing at both the single species and ecosystem level (Bruchac 2003: 159; Marshall 1995). Like humans, wolves proved capable of associating with and maintaining cordial relations with other species, such as ravens.

When I closely examined the stories from Indigenous plains peoples of North American, it became clear that wolves were considered to be important teachers who helped humans in their efforts at hunting (Fogg et al. 2015; Schlesier 1987). "For some tribes, the First People include a noble, heroic figure, such as the Wolf among the Comanche, who foresees 
the coming of humanity and plans a perfect, ideal world for them-until his brother Coyote enters the scene as marplot" (Bright 1987).

It became obvious to me that the way the Shoshone and Comanche see the wolf and the coyote reflect their understanding of natural phenomena. Wolf (Pia $I s^{\prime} a$, pronounced Pee'a Eeesha) is seen as the Creator figure, and Coyote $\left(I s^{\prime} a\right)$ is his/her little brother who, like many younger siblings, is constantly trying to improve upon its older sibling's efforts (Buller 1983; Ramsey 1977; Vander 1997). Coyote is not seen as an evil figure. $\mathrm{He} / \mathrm{she}$ is thought of more as mischievous; a sort of sub-creator, which is why he is described as the little brother of Wolf and not as an opponent, except possibly in the intellectual sense.

Wolf was wholly beneficent; his acts of original creation made all things perfect and good. Coyote, the mischievous Til Eulenspiegel of Shoshonean folklore, was the spoiler of all things, however. His was the role of the transformer who undid the good works of his big brother. He brought hardship, travail and effort into the lives of men. He represented the force of Evil as we (EuroAmericans) see it-an yet the Shoshones in no way thought of him and his relationship with Wolf as a conflict of good and evil. Coyote was not bad, he was no more than wantonly mischievous (Wallace and Hoebel 1948:193-194).

Thus, in the tradition of the Nubmub/Newe (Shoshone and Comanche peoples) Wolf was considered as the creator figure who created a perfect world (Harney 1995:26; Smith and Hayes 1993). At times Wolf lost patience with his creation, as in the Paiute story, Tracks of the Creator (Ramsey 1977:231).

According to the Numic tradition, Wolf and Coyote argued about how the world should function, with Wolf desiring an idealized world in which death is only temporary, childbirth is easy and pleasant for women, and winter does not exist. In contrast, Coyote thinks death should be permanent, childbirth should be difficult, and hardships and cold weather should be regular aspects of human experience (Lily Pete, in Smith 1993:3-4). That canids would carry out a human-style dialog is clearly unrealistic, and reveals the metaphorical error in this tradition. Nonetheless, this discussion reflects perceptions of the way the world actually functions (Harney 1995; Smith 1993). Children are taught to emulate Wolf and view Wolf as a more sympathetic figure than Coyote, however, it is Coyote who presents the more realistic view of how the world truly functions. In the long run, it is obvious who will usually carry the day.

Even though they acknowledge the sadness that resulted from death, which they attribute to Coyote's thinking, the Newe themselves recognize that "If it weren't for Coyote there would be too many people now" (Lily Pete, in Smith and Hayes 1993:3). This recognition reveals the truth behind the troubling reality, and shows that the people recognize the risks of local human overpopulation on potentially limiting sources of food, water, and other resources. Numic peoples were known to practice family planning hundreds of years before this became a concept in other cultural traditions (Wallace and Hoebel 1948).

\section{Evaluating Myth: Balanced Nature vs. Lupine Creator}

Both the idea of balance in nature and of Wolf functioning as a creator figure were myths essential to my development. For a time, I was inclined towards the Balance of Nature way of thinking, however, revisiting my roots after working with Native American colleagues led me back to stories I had once considered to not be based in real phenomena. I was drawn to the Balance of Nature myth, because it seemed well thought out and grounded in reality. In contrast, the idea of Wolf as a creator figure seemed to come from the realm of the imagination. The reality I understand today, however, is quite different. I now recognize that the Balance of Nature concept seemed logical, because academic scholars typically privilege ideas from the Western philosophical tradition, and this was the tradition in which my university education took place. Today, more careful examination on my part has revealed little of substance behind apparently rational Western concepts, and the sources of bias that lead them to serious error. The metaphors that underlie the Balance of Nature come from the Western European Liberal tradition and economic capitalism. It is said that liberals have an easier time conceiving of the end of the world than of the end of capitalism (Fawcett 2015). Ecological theory is rife with economic metaphors, probably because most of its practitioners come from this liberal philosophical tradition.

Over the last few decades, modern ecological and evolutionary thinking has turned away from these economically driven metaphors into a more sophisticated and complex understanding of how environments and organisms interact through the study of what is now described as ecological developmental biology or Eco/Devo (Gilbert and Epel 2015; Sultan 
2015). This new field argues that phenotypes arise through constant interaction with their environments, both external and internal, and that cooperative relationships among organisms are more important than competitive ones (Pierotti 2011a). The idea of competition dominating ecology is yet another metaphor derived from capitalist economics, which assumes that competition is much more important than cooperation-a concept interpreted to have Marxist overtones.

In contrast, theory derived from Eco/Devo shares important thematic elements with the ideas that All Things are Connected and All Things are Related, which are defining myths of Indigenous thinking (Pierotti 2011a, b). By emphasizing cooperation as opposed to competition among species, Native stories provide an intellectual framework within which I could appropriately consider the idea of wolves as cultural creators. As modern humans (Homo sapiens) moved into new environments they had to figure out how to survive, a situation far from guaranteed as humans left the relatively mild climates of Africa and moved into the more rigorous environments of Europe, Asia, and eventually North America, during times of intermittent glaciation. To do this effectively they adjusted their behavior and hunting techniques to cooperate with another social predator, that was already successfully exploiting these environments, the wolf, Canis lupus. Interacting and cooperating with wolves led to new cultural traditions and understandings (Pierotti and Fogg In press; Schleidt and Shalter 2003; Shipman 2014, 2015). As the agent responsible for these cultural changes, wolves were identified as creator figures, i.e. the driving force behind a new way of living in an unpredictable and often harsh environment (Pierotti 2011a).

Despite this new updated logic, this interpretation still reveals why it is typically assumed that myth is based upon erroneous assumptions. I have learned over decades that scholars from the Western philosophical tradition have difficulty accepting that nonhumans could be crucial in shaping the cultural traditions of humans. This is especially true if humans did not initiate and control the dynamics of the interaction. Anderson (1996) discusses such departures from apparent rational thought in terms of apparent "errors." As Anderson phrases it, "Granted that error is ever with us, why pick one error over another" (1996:9). His answer is that humans in nonwestern traditions do not settle on useless approximations of facts. Instead, they choose what he refers to as "useful errors," which provide emotionally satisfying insights.

To conclude, both the ideas of a Balance of Nature and of Wolves as Creator Figures contain "useful errors." Each provides emotionally and aesthetically satisfying explanations of complex phenomena. The difference lies not in the myths themselves, but in the systems from which they derive their metaphors. Capitalism, which underpins the idea of Balance of Nature, has proven to be inaccurate and inadequate in providing explanatory metaphors for evolutionary biology in the twenty-first century. In contrast, the idea of different species shaping one another's behavior and ecological niches, from which culture can arise, has proven to be much more likely within the framework of contemporary thinking on evolution and ecology. What this suggests is that the ideas of relatedness and connectedness that are characteristic of Indigenous thought (Pierotti 2011a, b) can be more accurate reflections of how nature functions than are industrial age economic models and concepts.

\section{Acknowledgements}

I thank Gene Anderson for providing inspiration and insight both through discussions and in his many writings, and also for coming up with the concept of "useful errors." The writings of Donald Worster provided insight into issues underlying the idea of balance in nature. I thank my mother and grandmother for introducing me to stories from Numic traditions, and Peter D. Wolf, Tabananika and Nuhmuhnuh for showing me what these ideas meant in real life. Finally, I thank three anonymous reviewers on this MS for their comments and insights.

\section{Declarations}

Permissions: None declared.

Sources of Funding: None declared.

Conflicts of Interest: None declared.

\section{References Cited}

Anderson, E. N. 1996. Ecologies of the Heart: Emotion, Belief, and the Environment. Oxford University Press, New York, NY.

Anderson, E. N. 2013. What shapes Cognition: Traditional Sciences and Modern International Science. In Explorations in Ethnobiology: The Legacy of Amadeo Rea, edited by M. Quinlan and D. Lepof- 
sky, pp. 47-77. Society of Ethnobiology, Denton, TX.

Annett, C. A., and R. Pierotti. 1989. Chick Hatching as a Trigger for Dietary Switches in Western Gulls. Colonial Waterbirds 12:4-11.

Annett, C. A., and R. Pierotti. 1999. Longterm Reproductive Output and Recruitment in Western Gulls: Consequences of Alternate Foraging Tactics. Ecology 80:288-297.

Bright, W. 1993. A Coyote Reader. University of California Press, Berkeley, CA.

Bringhurst, R. 2008a. Everywhere Being is Dancing: 20 Pieces of Thinking. Counterpoint Press, Berkeley, CA.

Bruchac, J. 2003. Our Stories Remembered: American Indian History, Culture, and Values through Storytelling. Fulcrum Press, Golden, CO.

Buller, G. 1983. Comanche and Coyote, the Culture Maker, In Smoothing the Ground, edited by B. Swann, pp. 245-258. University of California Press, Berkeley, CA.

Peter U. Clark, Arthur S. Dyke, Jeremy D. Shakun, Anders E. Carlson, Jorie Clark, Barbara Wohlfarth, Jerry X. Mitrovica, Steven W. Hostetler, A. Marshall McCabe. 2009. The Last Glacial Maximum. Science 325:710-714.

Darwin, C. 1859. The Origin of Species by Means of Natural Selection. Studio Editions, London.

Tom D. Dillehay, Carlos Ocampo, José Saavedra, Andre Oliveira Sawakuchi, Rodrigo M. Vega, Mario Pino, Michael B. Collins, Linda Scott Cummings, Iván Arregui, Ximena S. Villagran, Gelvam A. Hartmann, Mauricio Mella, Andrea González, George Dix. 2015. New Archaeological Evidence for an Early Human Presence at Monte Verde, Chile. PLOS ONE 10:e0141923. DOI:10.1371/journal.pone.0141923.

Elton, C. S. 1927. Animal Ecology, MacMillan, New York, NY.

Fawcett, E. 2015. Liberalism: The Life of an Idea. Princeton University Press, Princeton, NJ.

Finley, C. 2011. All the Fish in the Sea: Maximum Sustainable Yield and the Failure of Fisheries Management. University of Chicago Press, Chicago, IL.

Fogg, B. R., N. Hernandez, and R. Pierotti. 2015.
Relationships between Indigenous American Peoples and Wolves 1: Wolves as Teachers and Guides. Journal of Ethnobiology 35:262-285.

Gibbons, A. 2013. How a Fickle Climate Made Us Human. Science 341:474-479.

Gibbons, A. 2015. Humans May Have Reached Chile by 18,500 Years Ago. Science 350: 898.

Gilbert, S. F. and D. Epel. 2015. Ecological Developmental Biology: The Environmental Regulation of Development, Health, and Evolution. Sinauer Associates, Sunderland, MA.

Harney, C. 1995. The Way It Is: One Water-One AirOne Mother Earth. Blue Dolphin Publications, Nevada City, CA.

Hesse, M. 1974. The Structure of Scientific Inference. University of California Press, Berkeley, CA.

Holt, S. J. 1975. The Concept of Maximum Sustainable Yield (MSY) and Its Application to Whaling. FAO/UN Scientific Consultation on Marine Mammals. Document ACMRR/MM/SC/4.

Kingsland, S. E. 1985. Modeling Nature: Episodes in the History of Population Ecology. The University of Chicago Press, Chicago, IL.

Kricher, J. 2009. The Balance of Nature: Ecology's Enduring Myth. Princeton University Press, Princeton, NJ.

Larkin, P. A. 1977. An Epitaph for the Concept of MSY. Transaction of the American Fisheries Society 106:1-11.

Lorenzen, E.D. D. Nogués-Bravo, L. Orlando, J. Weinstock, J. Binladen, K. A. Marske, A. Ugan, M. K. Borregaard, M. T. P. Gilbert, R. Nielsen, S. Y. W. Ho, T. Goebel, K. E. Graf, D. Byers, J. T. Stenderup, M. Rasmussen, P. F. Campos, J. A. Leonard, K. Koepfli, D. Froese, G. Zazula, T. W. Stafford, K. Aaris-Sørensen, P. Batra, A. M. Haywood, J. S. Singarayer, P. J. Valdes, G. Boeskorov, J. A. Burns, S. P. Davydov, J. Haile, D. L. Jenkins, P. Kosintsev, T. Kuznetsova, X. Lai, L. D. Martin, H. G. McDonald, D. Mol, M. Meldgaard, K. Munch, E. Stephan, M. Sablin, R. S. Sommer, T. Sipko, E. Scott, M. A. Suchard, A. Tikhonov, R. Willerslev, R. K. Wayne, A. Cooper, M. Hofreiter, A. Sher, B. Shapiro, C. Rahbek, E. Willerslev. 2011. Species-Specific Responses of Late Quaternary Megafauna to Climate and 
Humans. Nature 479:359-363.

Marshall, J. 1995. On Behalf of the $W$ olf and the First Peoples. Red Crane Books, Santa Fe, NM.

Pennisi, E. 2004. Ice Ages May Explain Ancient Bison's Boom-Bust History. Science 306:1454.

Pierotti, R. 1981. Male and Female Parental Roles in the Western Gull under Different Environmental Conditions. Auk 98:532-549.

Pierotti, R. 2011a. Indigenous Knowledge, Ecology, and Evolutionary Biology. Routledge Press, New York, NY.

Pierotti, R. 2011b. The World According to Is'a: Combining Empiricism and Spiritual Understanding in Indigenous Ways of Knowing. In Ethnobiolo$g y$, edited by E. N. Anderson, D. M. Pearsall, E. S. Hunn, and N. J. Turner, pp. 65-81. Wiley-

Blackwell, Hoboken, NJ.

Pierotti, R., and C. A. Annett. 1987. Reproductive Consequences of Specialization and Switching in an Ecological Generalist. In Foraging Behavior, edited by A. C. Kamil, J. R. Krebs, and H. R. Pulliam, pp. 417-442. Plenum Press, New York, NY.

Pierotti, R., and C. A. Annett. 1990. Diet and Reproductive Performance in Seabirds. Bioscience 40:568574.

Pierotti, R., and C. A. Annett. 1991. Diet Choice in the Herring Gull: Effects of Constraints Imposed by Reproduction and Ecology. Ecology 72:319-328.

Pierotti, R., and C. A. Annett. 1994. Patterns of Aggression in Gulls: Asymmetries and Tactics in Different Roles. Condor 96:590-599.

Pierotti, R., and B. Fogg. In press. The First Domestication: Co-evolution between Homo sapiens and Canis lupus. Yale University Press, New Haven, CT.

Ramsey, J. 1977. Coyote Was Going There: Indian Literature of the Oregon Country. University of Washington, Seattle, WA.

Schleidt, W. M., and M. D. Shalter. 2003. Coevolution of Humans and Canids: An Alternative View of Dog Domestication: Homo Homini Lupus? Evolution and Cognition 9:57-72.

Schlesier, K. H. 1987. The Wolves of Heaven: Cheyenne
Shamanism, Ceremonies, and Prehistoric Origins. Civilization of the American Indian Series, No. 183. University of Oklahoma Press, Norman, OK.

Shapiro B, A. J. Drummond, A. Rambaut. M.C. Wilson, P.E. Matheus, A. V. Sher, O. G. Pybus, M. T. Gilbert, I. Barnes, J. Binladen, E. Willerslev, A. J. Hansen, G. F. Baryshnikov, J. A. Burns, S. Davydov, J. C. Driver, D. G. Froese, C. R. Harington, G. Keddie, P. Kosintsev , M. L. Kunz, L. D. Martin, R. O. Stephenson, J. Storer, R. Tedford, S. Zimov, A. Cooper. 2004. Rise and Fall of the Beringian Steppe Bison. Science 306:15611564.

Shipman, P. 2014. How Do You Kill 86 Mammoths? Taphonomic Investigations of Mammoth Megasites. Quaternary International 359-360:1-9.

Shipman, P. 2015. The Invaders: How Humans and Their Dogs Drove Neandertals to Extinction. Harvard University Press, Cambridge, MA.

Smith, A. M., and A. C. Hayes. 1993. Shoshone Tales. University of Utah Press, Salt Lake City, UT

Stephens, D. W., and J. R. Krebs. 1986. Foraging Theory. Princeton University Press, Princeton, NJ.

Sultan, S. E. 2015. Organism and Environment: Ecological Development, Niche Construction and Adaptation. Oxford University Press, New York, NY.

Tinbergen, N. 1953. The Herring Gulls' World. Basic Books, London.

Vander, J. 1997. Shoshone Ghost Dance Religion: Poetry Songs and Great Basin Context. University of Illinois Press, Chicago.

Wallace, E., and E. A. Hoebel. 1948. Comanches: Lords of the South Plain. University of Oklahoma Press, Norman, OK.

Worster, D. 1993. The Wealth of Nature. Oxford University Press, Oxford.

Worster, D. 1994. Nature's Economy: A History of Ecological Ideas, 2nd Edition. Cambridge University Press, Cambridge.

Zimmerman, C., and K. Cuddington. 2007. Ambiguous, Circular and Polysemous: Students' Definitions of the "Balance of Nature" Metaphor. Public Understanding of Science 16:393-406. 